Int. J. Dev. Biol. 51: 521-533 (2007)

doi: $10.1387 / \mathrm{ijdb} .072381 \mathrm{jb}$

\title{
Patterning and morphogenesis of the vertebrate inner ear
}

\author{
JINWOONG BOK, WEISE CHANG and DORIS K. WU* \\ National Institute on Deafness and Other Communication Disorders, Rockville, MD, USA
}

\begin{abstract}
The positional cues for formation of individual inner ear components are dependent on pre-established axial information conferred by inductive signals from tissues surrounding the developing inner ear. This review summarizes some of the known molecular pathways involved in establishing the three axes of the inner ear, anterior-posterior (AP), dorsal-ventral (DV) and medial-lateral (ML). Signals required to establish the AP axis of the inner ear are not known, but they do not appear to be derived from the hindbrain. In contrast, the hindbrain is essential for establishing the DV axis of the inner ear by providing inductive signals such as Wnts and Sonic hedgehog. Signaling from the hindbrain is also required for the formation of the ML axis, whereas formation of the lateral wall of the otocyst may be a result of first establishing both the AP and DV axes. In addition, this review addresses how genes induced within the otic epithelium as a result of axial specification continue to mediate inner ear morphogenesis.
\end{abstract}

KEY WORDS: inner ear, morphogenesis, vertebrate, axial specification, patterning

The vertebrate inner ear is a highly intricate organ (Figure 1). One of the earliest events during inner ear formation is the acquisition of its axial identity from surrounding tissues. In amniotes, this process most likely begins after otic placode formation and involves early cell fate decisions. These early decisions can be classified into three categories: neural, sensory and non-sensory. Neural-fated cells delaminate from the otic epithelium to form neurons of the cochleovestibular ganglion (CVG). Sensory-fated cells eventually develop into sensory hair cells and supporting cells that form various sensory patches within elaborate nonsensory structures. Sensory and non-sensory fated cells most likely interact with each other to coordinate the morphogenetic process. Identifying the inductive signals that confer axial identity and the cascades of molecular and cellular events that follow are essential for elucidating inner ear morphogenesis.

\section{Axial specification of the inner ear}

The locations where otic placodes develop along the body axis are thought to be dependent on Fibroblast growth factors (Fgfs) emanating from the mesoderm, endoderm and hindbrain (Noramly and Grainger, 2002, Ladher et al., 2005). Details of the otic placode inductive process will be covered by other reviews in this issue. Analyses of mouse hindbrain mutants such as kreis/er, Hoxa1 and Fgf3 suggest that the lack of Fgf signaling in the hindbrain alone does not affect placode formation but rather affects subsequent morphogenetic events (Kiernan et al., 2002). There is some indication that inner ear malformations in these hindbrain mutants may be due to defects in axial patterning (Choo et al., 2006). In chicken, otic axial specification occurs after placode formation, whereas this process appears to occur much earlier in salamanders (Harrison, 1936, Bok et al., 2005). The timing of axial specification in mice is not clear. Specification of the antero-posterior (AP) axis of the chicken inner ear appears to occur before the dorso-ventral (DV) axis (Wu et al., 1998), similar to the neural tube and other organs (Lumsden and Krumlauf, 1996). The specifications of individual axis are discussed in the following sections (Figure 2).

\section{Anteroposterior axis}

It is likely that the initiation of the AP axis of the inner ear begins with the expression of several neural/sensory markers such as Fgf10, Lunatic fringe (Lfng), Delta1, Neurogenin1 (Ngn') and NeuroDin the anterior region of the invaginating otic placode/cup where neuroblasts delaminate to form the cochleovestibular ganglion (Myat et al., 1996, Morsli et al., 1998, Cole et al., 2000, Alsina et al., 2004). However, otic transplantation studies in chicken embryos suggest that the AP axis of the inner ear is not fixed when these neurosensory markers are first detected and the specification process occurs gradually over approximately a 12 hour-period until the otic cup is half-closed (Wu et al., 1998, Bok et al., 2005). Thus, the signals conferring AP axial identity to the otic placode are most likely available before the appearance of the neurosensory markers and present continuously until after the specification process is completed.

Abbreviations used in this paper: AP, anterior-posterior; CVG, cochleovestibular ganglion; DV, dorsal-ventral; ML, medial-lateral.

\footnotetext{
*Address correspondence to: Doris K. Wu. NIDCD, 5 Research Ct., Rm 2B34, Rockville, MD 20850. Fax: +1-301-402-5475. e-mail: wud@nidcd.nih.gov
} 
The developing hindbrain would be a reasonable tissue for providing $\mathrm{AP}$ axial information to the otic tissue, since it is organized into transient segments known as the rhombomeres. Each rhombomere expresses a unique profile of genes. This unique segmentation of rhombomeres is though to coordinate locations of the sensory ganglia along the AP axis of the hindbrain as well as the exit routes of neural crest cells that pattern the head and facial structures during embryogenesis (Trainor and Krumlauf, 2000, Graham et al., 2004). Interestingly, the anterior and posterior half of the otic cup are adjacent to rhombomeres 5 and 6 ( $r 5$ and $r 6$ ) and it has been proposed that the $r 5 / 6$ boundary may play a role in inner ear patterning (Brigande et al., 2000b). Moreover, the formation of $r 5 / 6$ boundary in chicken occurs quite early (6somite stage), even before otic placode induction is completed (Fraser et al., 1990, Groves and Bronner-Fraser, 2000). Therefore, the differential gene expression patterns between r5 and r6 could provide AP positional information to the inner ear. However, this hypothesis has not received much experimental support so far. When the relative positions of $r 5$ and $r 6$ were switched in ovo before the AP axis of the chicken inner ear was fixed, AP axial pattern of the inner ear was not affected (Bok et al., 2005), suggesting that AP orientation of $r 5$ and $r 6$ does not play a major role in conferring AP axial identity to the inner ear.

While the tissue(s) responsible for providing AP axial identity to the inner ear remains unknown, recent studies suggest that Tbx 1 could be a key downstream target of extrinsic AP signaling (Vitelli et al., 2003, Raft et al., 2004, Arnold et al., 2006). In the mouse, Tbx 1 expression is found exclusively in the posterior half of the otic cup (Vitelli et al., 2003, Raft et al., 2004, Arnold et al., 2006). Interestingly, in Tbx1 null mutants, the expression domains of genes such as Ngn1, NeuroD1, Lfng and Fgf3lose their normal anterior restriction in the otocyst and expand into more posterior regions. In contrast, the expression domains of posterior-expressed genes such as Otx1, Otx2 and Goosecoid are abolished (Vitelli etal., 2003, Raft etal., 2004, Arnold etal., 2006). Moreover, the expression domains of Ngn1 and NeuroD1 are significantly reduced in a transgenic mouse line carrying multiple copies of human TBX1(Raft et al., 2004). Together, these results suggest that Tbx1 normally functions to suppress or restrict the anterior, neuro-sensory fate and that $T b \times 1$ could be an important determinant of AP axial identity within the inner ear. Based on conditional knockout studies of $T b \times 1$, this role of $T b \times 1$ is mediated by its expression within the otic epithelium rather than its expression in the surrounding mesenchyme (Arnold et al., 2006). Identifying the signal(s) that regulates $T b \times 1$ expression in the otic epithelium will be important in understanding AP axial specification in the inner ear.

\section{Dorsoventral axis}

A mature mouse and chicken inner ear is composed of two major parts, a dorsal vestibular component and a ventral auditory component (Figure 1). Based on gene expression patterns, the induction of DV axis is also an early event. Genes associated with the dorsal vestibular structures such as $D / \times 5, D / \times 6, H m \times 2, H m \times 3$ and $G b \times 2$, or ones with ventral auditory and neurosensory regions such as Lfng, Ngn1, NeuroD1, Sox2and Six 1, are asymmetrically expressed in the otic cup stage in both chicken and mice (Fekete and Wu, 2002). Nevertheless, transplantation experiments in chicken demonstrated that the DV axis of the inner ear is not specified until well after otocyst formation (Wu etal., 1998). These results suggest that while the asymmetry of gene expression patterns along the AP and DV axes appears around the same time, commitment of the DV axis occurs much later than that of the AP axis (Wu et al., 1998).

Unlike the AP axis, the DV axial specification of the inner ear is mainly dependent on signals emanating from the hindbrain (Bok et al., 2005). When a segment of hindbrain adjacent to the inner ear is rotated along its DV axis in ovo, genes normally expressed in the ventral otocyst such as $\angle f n g$, NeuroD 1 and Six 1 are shifted dorsally. On the other hand, the expression of a dorsal otic gene, Gbx2, is abolished. These results indicate that by rotating the DV axis of the hindbrain, ventral hindbrain tissues are sufficient to confer ventral fates to dorsal otic tissue (Bok et al., 2005). Thus, the ability of the ventral hindbrain to override other potential dorsalizing signals from neighboring tissues further suggests that the hindbrain provides the major DV axial information to the inner ear.

Secreted molecules from the hindbrain such as Wnts from the dorsal neural tube and Sonic hedgehog (Shh) from the floor plate and notochord play important roles in establishing the DV axis of the inner ear (Liu et al., 2002, Riccomagno et al., 2002, Bok et al., 2005, Riccomagno et al., 2005). These secreted molecules are also involved in DV patterning of neurons within the hindbrain as well as other paraxial structures such as the somites (Ikeya et al., 1997, Tajbakhsh and Sporle, 1998, Lee and Jessell, 1999, Ruiz i Altaba et al., 2003). Analyses of the inner ears from Wnt1/Wnt3a double knockouts show that Wnt signaling is responsible for the expression of a subset of dorsal otic genes such as $D / \times 5, D / \times 6$ and Gbx2 (Riccomagno et al., 2005). Moreover, tissue ablation experiments carried out in otic explant cultures clearly demonstrated that the Wnts responsible for the expression of these dorsal otic genes are emanating from the dorsal hindbrain (Riccomagno et al., 2005). Consistent with the loss of $D / \times 5, D / \times 6$ and $G b \times 2$ expression domains, the inner ears of $W n t 1 / W n t 3 a$ double mutants fail to develop any identifiable vestibular structures (Riccomagno et al., 2005), establishing that Wnt signaling is required for specification of the dorsal inner ear.

Shh is required for the ventral patterning of the inner ear in both chicken and mice (Liu et al., 2002, Riccomagno et al., 2002, Bok et al., 2005). In Shh-/- mouse embryos, the expression levels of genes in the ventral portions of the otocyst such as Otx1, Otx2, Lfng, Fgf3, Ngn1 and NeuroD1 are reduced, resulting in the complete absence of ventral inner ear structures (Riccomagno et al., 2002). In chicken, injecting hybridoma cells, which secrete antibodies blocking Shh bioactivity, into the ventral midline at the otic cup stage also resulted in inner ears devoid of ventral structures (Bok et al., 2005). Shh signaling is mediated by the Gli family of transcription factors (Ingham and McMahon, 2001). Analyses of several mouse lines carrying various genetic combinations of mutant alleles associated with the Shh/Gli signaling pathway suggest that a proper balance of Gli3 repressor and Gli2/ Gli3 activators along the DV axis is critical for mediating graded levels of Shh signaling in the inner ear (see below, Bok et al., 2007).

What is the relationship between Wnts and Shh in inner ear development? Do their actions oppose each other in the inner ear? Shh signaling from the ventral floor plate and notochord appears to restrict Wnt activities dorsally in the inner ear since the 


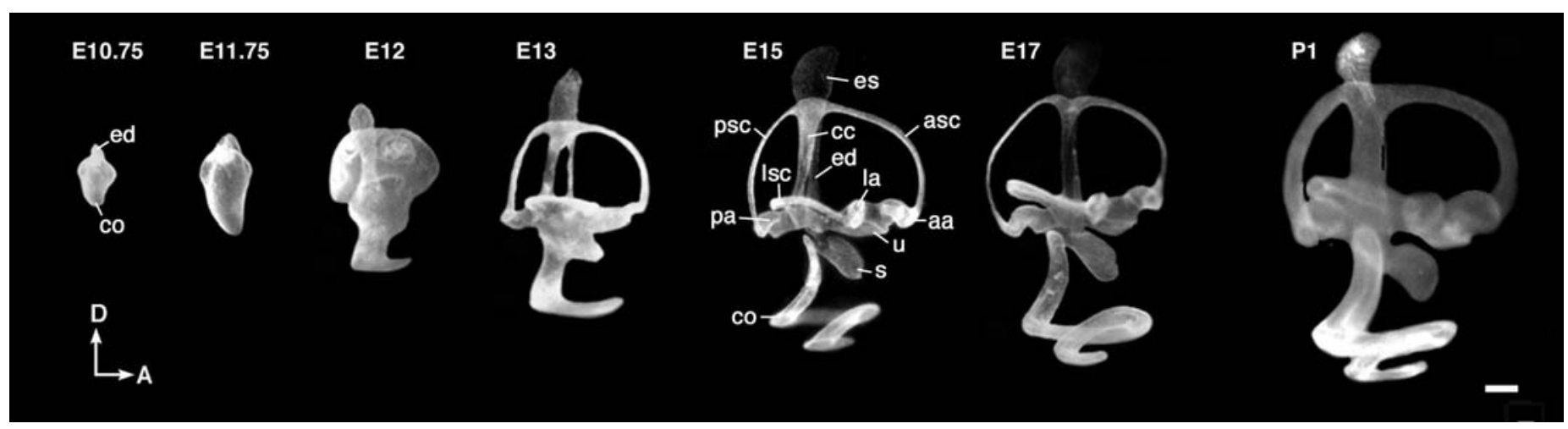

Fig. 1. Developmental series of the mouse inner ear. Lateral views of paint-filled, membranous labyrinths of mice from embryonic days 10.75 (E10.75) to postnatal day 1 (P1). Abbreviations: aa, anterior ampulla; asc, anterior semicircular canal; cc, common crus; co, cochlear duct; ed, endolymphatic duct; es, endolymphatic sac; la, lateral ampulla; Isc, lateral semicircular canal; pa, posterior ampulla; psc, posterior semicircular canal; s, saccule; u, utricle, D, dorsal; A, anterior. Scale bar, $200 \mu \mathrm{m}$. Adapted from Cantos et al., 2000.

expression domains of genes that are regulated by Wnts such as DIX5and Gbx2expanded ventrally in Shh-/-embryos (Riccomagno et al., 2002, Riccomagno et al., 2005). However, when Wnt signaling is abolished or ectopically activated, expression domains of genes that are putatively downstream of Shh such as Gli1, Ngn1, Otx2 and Pax2 in the ventral otic domain did not change (Riccomagno et al., 2005), indicating that the ventral restriction of Shh signaling is not mediated by Wnts.

Several lines of evidence suggest that Wnts and Shh are not the only signals involved in establishing the DV axis of the inner ear. The lack of Wnts in the hindbrain only affected some of the dorsal otic genes including $D / \times 5, D / \times 6$ and $G b \times 2$, yet other dorsal otic genes such as $H m \times 3$ and $W n t 2 b$ were not affected, suggesting that other dorsal signals are still operating (Riccomagno et al., 2005). Another family of secreted molecules that may serve as signaling molecules for the inner ear patterning are Bone morphogenetic proteins (Bmps), which are expressed in the roof plate of the hindbrain and dorsal ectoderm (Lee and Jessell, 1999). Since Bmp and Shh inhibit each other in the neural tube and inhibitors of BMPs, expressed in the notochord, also modulate Shh functions in the ventral neural tube (Liem etal., 1995, Liem etal., 2000, Patten and Placzek, 2002), it is possible that similar opposing interactions between Shh and Bmps occur in the inner ear. A similar multi-signaling hypothesis for DV patterning of the hindbrain has been proposed for establishing the central cochlear and vestibular nuclei (Maklad and Fritzsch, 2003).

Six1, a transcription factor expressed in the ventral otocyst, is also required for ventral patterning of the inner ear (Zheng et al., 2003, Ozaki et al., 2004). The expression levels of ventral otic genes including Otx1, Otx2, Fgf3, Fgf10 and Lfng are greatly reduced and the expression domains of dorsal otic genes such as $D / \times 5, H m \times 3$, Gata3, Dach1 and Dach2 are expanded ventrally (Zheng etal., 2003, Ozaki etal., 2004). Interestingly, Six1 expression is not altered in Shh-null inner ears, suggesting that Six 1 is not regulated by Shh in the inner ear (Ozaki et al., 2004). Rather, Eya1, whose expression domain overlaps with Six 1 in the otic epithelium, has been implicated in Six1 regulation (Xu et al., 1999). Signals regulating Eya1 or Six 1 expression in the ventral otic area are unclear. However, when the DV axis of the hindbrain is rotated, the normal ventral Six 1 expression domain in the inner ear is shifted dorsally, suggesting that the signal(s) regulating
Six 1 expression in the inner ear is emanating from the ventral hindbrain (Bok et al., 2005). Therefore, these results suggest that there is at least one other signaling from the hindbrain, independent of Shh, that mediates ventral patterning of the inner ear via regulation of Six1.

\section{Mediolateral axis}

Tissues and signals providing the ML axial identity to the inner ear are not clear. In a mature inner ear, the endolymphatic duct is a medial structure and the lateral semicircular canal and ampulla are lateral structures. In contrast, the anterior and posterior semicircular canals and the cochlear duct could develop from a combination of medial and lateral domains (Figure 1) (Fekete and $\mathrm{Wu}, 2002)$. The $\mathrm{ML}$ axis may be the last of the axes to be established because the lateral domain technically does not exist until the otic cup closes. However, several lines of evidence support the notion that medial identity is acquired early. First, altering the $M L$ axis of the developing otocyst in chicken results in severely malformed inner ears without re-specification of medially or laterally expressed genes (Wu et al., 1998). While the exact timing of ML axial specification is not clear, it is occurring approximately at the same time as the AP axis and both are committed before the DV axis is fixed (Wu et al., 1998). Therefore, despite the fact that the lateral otic region is the last one to form, some aspects of the $\mathrm{ML}$ axis appear to occur relatively early.

Second, genes that are activated early in the otic placode such as Gbx2 and Pax2 are associated with the medial region of the inner ear at later stages (Groves and Bronner-Fraser, 2000, Hidalgo-Sanchez etal., 2000, Burton etal., 2004, Lin etal., 2005). These expression patterns imply early specification of the medial identity. Alternatively, a counter argument is that medial identity is acquired only after Gbx2 and Pax2 expression domains become restricted from their broad distribution during the otic placode stage.

Third, hindbrain mutants such as Hoxa1-/-, Fgf3-/-and kreis/er, which show defects in $\mathrm{r} 5$ and $\mathrm{r} 6$ as well as Fgf signaling, lack a definitive medial structure, the endolymphatic duct, in addition to other inner ear defects (Deol, 1964, Mansour et al., 1993, Mark et al., 1993, Choo et al., 2006). Consistently, knockout of one of the FGF receptors, Fgfr2(IIIb), also shows an absence of the endolymphatic duct as well as other defects (Mansour et al., 1993, 
A
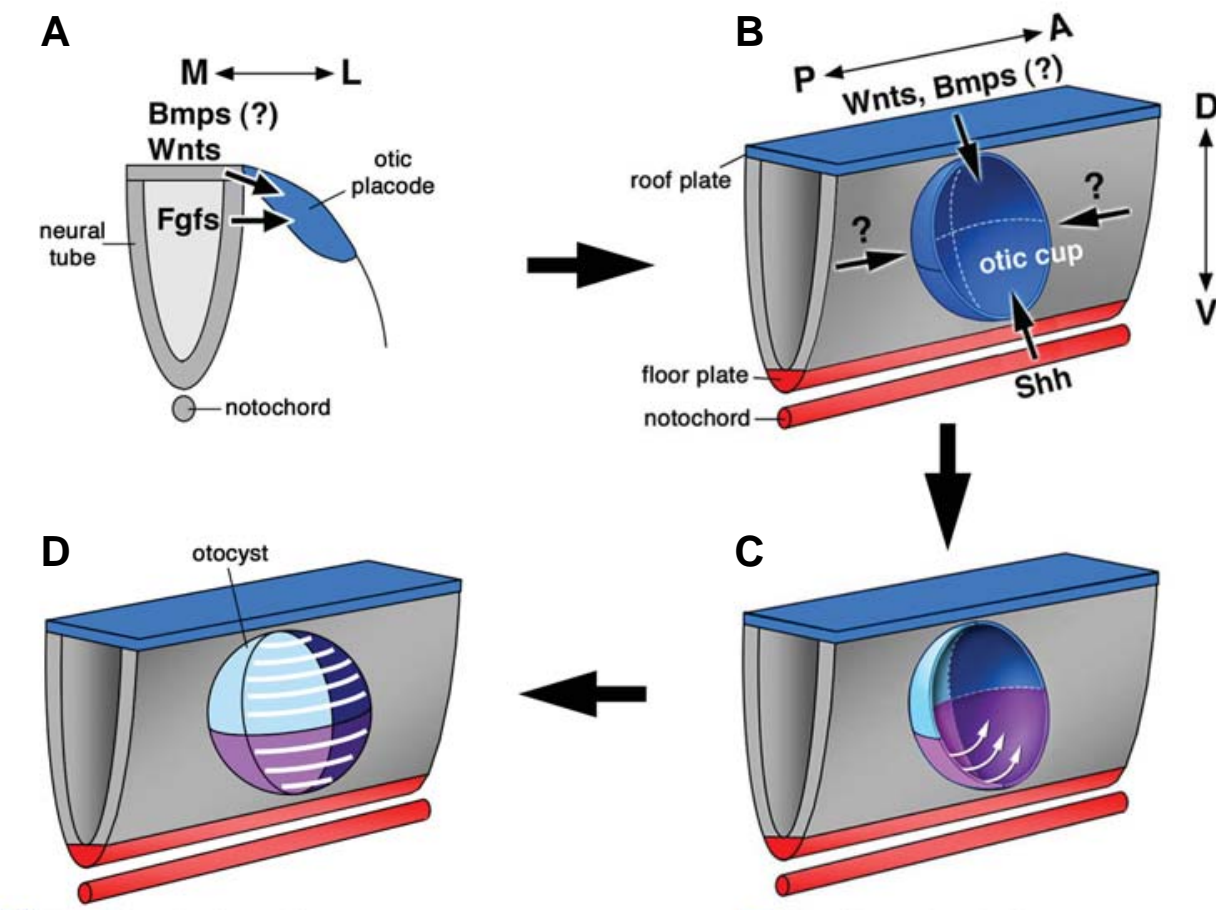

2

ADL: $H m \times 3, T b \times 1, D / x 5$

ADM: Gbx2, DIx5, Pax2

AVL: Lfng, Ngn1, NeuroD1, Delta1, Six1, Sox2

AVM: Lfng, Ngn1, NeuroD1, Delta1, Six1, Sox2, Pax2

PDL: Hmx3, Tbx1, DIx5

PDM: Gbx2, Pax2, DIx5

PVL: Tbx1, Otx1, Otx2

PVM: Pax2

Fig. 2. A model on the timing of axial specification for mouse and chicken inner ears. (A) Induction of the otic placode is dependent on signals produced by surrounding tissues including Wnts, Fgfs and possibly Bmps from the hindbrain. The medial axis is likely the first axis to be specified in the otic epithelium since the newly induced otic genes such as Gbx2 and Pax2 are associated with the medial region of the inner ear at later stages. (B,C) The invaginating otic placode receives AP and DV signals from the surrounding tissues, including Wnts and possibly Bmps from the dorsal hindbrain and Shh from the notochord and floor plate. Signal(s) that confer AP axial specification to the inner ear is not known but most likely involve the induction of Tbx1 in the posterior half of the otic cup. Tbx1, in turn, may function to restrict the anterior neuro-sensory domain expressing Ngn 1 , NeuroD1 and Lfng. Cells located in the ventral posterior region of the otic cup migrate dorsally to form most of the lateral wall of the otocyst except the neurosensory domain in the antero-ventral region. (D) The newly formed lateral wall of the otocyst continues to receive existing AP and DV signals and further express regional-specific genes. Abbreviations: $M$, medial; $L$, lateral; $A$, anterior; $P$, posterior; $D$, dorsal; $V$, ventral.

Pirvola et al., 2000). Therefore, FGF3 has been suggested as an important hindbrain-derived signaling molecule mediating inner ear development (McKay et al., 1996, Lin et al., 2005) and its key role could be specification of the medial axis.

More recently, detailed analyses of kreis/er mutants further revealed that, contrary to the loss of the endolymphatic duct, the lateral semicircular canal and ampulla are usually maintained in kreislermutants (Choo et al., 2006). In addition, in kreislerinner ears, genes expressed in the dorsal-medial otic region such as $G b \times 2$ and $W n t 2 b$ are downregulated, while the expression domain of $O t \times 2$, a gene that is normally restricted to the lateral otic region, is expanded medially, suggesting that the ML identity is affected (Choo et al., 2006). Similar patterning defects and gene expression changes are also observed in Gbx2 \%-mutants. In Gbx2-/- mutants, the endolymphatic duct is invariably affected, whereas the lateral semicircular canal and ampulla are usually normal (Lin et al., 2005). In addition, the dorso-medial expression domain of $D / \times 5$ is missing and the expression domain of a lateral gene, Otx2, is expanded medially, suggesting that the ML identity is also compromised in Gbx2-/-otocysts (Lin et al., 2005). Based on these results, it has been proposed that activation of $G b \times 2$ in the otic epithelium is a major molecular event downstream of signaling from the hindbrain. It remains to be examined if other hindbrain mutants that lack the endolymphatic duct, such as Hoxa 1and Fgf3nulls, also have gene expression changes similar to Gbx2\%- and kreis/ermutants.

Lastly, despite the fact that Wnt signaling originates from the dorsal hindbrain, fate mapping of Wnt-responsive cells in the mouse otic cup shows that these cells contribute broadly to the inner ear including the entire medial side (Riccomagno et al., 2005). This result is consistent with the finding that ventral inner ear structures are also severely affected in Wnt1-1-; Wnt3a-/- 
mutants (Riccomagno et al., 2005). A separate fate mapping study of the chicken otic cup using Dil shows that majority of the cells in the lateral wall of the otocyst are originated from the ventral posterior rim of the otic cup (Brigande et al., 2000a). Taken together both of these fate mapping studies, it is possible that cells in the otic cup are first displaced ventrally to encompass the entire medial side and then migrate dorso-laterally to form the lateral wall of the otocyst (Figure 2).

Based on all the evidence provided above, it is conceivable that the otic placode first acquires medial identity from Wnts and Fgfs emanating from the hindbrain, which leads to the activation of genes such as Pax2 and Gbx2. Then, AP orientation is imparted onto the invaginating otic placode by specifying the neurosensory domain. At the same time, ventral otic cells are exposed to Shh and other undefined signals from the ventral hindbrain, which confer ventral identity onto the medial fate and establishes DV differences. The combined AP and DV axial identities restrict the neurosensory domain to the antero-ventral region of the otic cup. The lateral fate is then determined when cells located in the ventro-posterior region of the otic cup migrate dorsally to form the lateral wall of the otocyst. The newly formed lateral region then continues to receive dorsalizing and ventralizing signals from the hindbrain, resulting in the generation of canals and cochlear duct, respectively (Figure 2 ).

\section{The morphogenetic process}

Most inner ear components consist of both sensory and nonsensory regions and the morphogenesis of these regions are most likely coordinated during development. The following section focuses on some of morphogenetic events that occur within the inner ear.

One major morphogenetic event is the subdivision of the putative neurosensory competent region into various sensory patches after neuroblast delamination (Figure 3). The major sensory organs in the vertebrate inner ear include the three cristae, maculae of the utricle and saccule and the auditory sensory organ (the organ of Corti in mammals and the basilar papilla in chicken). The molecular mechanisms underlying the specification of the neurosensory domain are thought to involve Sox2, Six1 and the Notch signaling pathway (Kelley, 2006). The lack of Sox2, Six1, or genes within the Notch signaling pathway such as Jagged1 and Delta1, affects ganglion formation as well as sensory organ development (Zheng et al., 2003, Ozaki et al., 2004, Kiernan et al., 2005, Brooker et al., 2006, Kiernan et al., 2006). Within the Sox2and Six 1expression domains, a subset of cells expresses $B m p 4$, whereas another major subset of cells expresses $L f n g$, a modulator of the Notch ligand-receptor interactions (Neves et al., 2007, Wu unpublished results). It is thought that the Bmp4-positive cells give rise to the three cristae, while the $\angle$ fng expressing cells give rise to the two maculae and the organ of Corti (Figure 3) (Morsli et al., 1998, Cole et al., 2000).

The formation of each sensory organ is coupled with the development of its non-sensory component. This coordinated development involves reciprocal interactions between the sensory and non-sensory tissues. For example, Fgf10 is expressed in the presumptive sensory domains, while its receptor FGFR2 (IIllb) is mainly expressed in the non-sensory epithelium (Pirvola et al., 2000). Fgf10 knockout mice show both sensory and non- sensory defects and targeted mutation of FGFR-2(IIIb) also results in severe malformation of non-sensory components as well as a failure of sensory organ development (Pirvola et al., 2000, Pauley et al., 2003). These results are the first to suggest that molecular interplay between the sensory and non-sensory components of the inner ear is important for their coordinated and correct formation. More recent studies suggest specifically that cristae dictate the formation of their associated non-sensory components, the semicircular canals.

\section{Crista and semicircular canal formation}

The three cristae and their associated semicircular canals are responsible for detecting angular head movements. These structures are derived from vertical and horizontal pouches of the developing otocyst. Over time, the opposing epithelia in the center region of each prospective canal within the pouches come together, fuse and resorb, leaving behind a tube-shaped canal. As a result of the resorption processes, the vertical pouch develops into the anterior and posterior canals joined together by the common crus and the horizontal pouch forms the lateral canal (Figure 1). Many determinants affect the formation of this vestibular apparatus, including extrinsic signals from surrounding tissues, proper canal pouch formation and regulated resorption.

\section{Extrinsic factors regulating crista and canal formation}

Wnt signaling emanating from the dorsal hindbrain is important for establishing the vestibular fate in the dorsal otic region by regulating a subset of dorsal otic genes such as $G b \times 2, D / \times 5$ and $D / \times 6$ (Riccomagno et al., 2005). The inner ears of Gbx2, D/x5 single, or $D / \times 5 / D / \times 6$ double knockout mutants all show defects in crista and canal development (Merlo et al., 2002, Lin et al., 2005, Robledo and Lufkin, 2006). This is consistent with the observation that no discernable vestibular apparatus is present in Wnt/Wnt3a double mutant embryos (Riccomagno et al., 2005). In contrast, the $\mathrm{Hmx}$ family of transcription factors, which has also been implicated in canal formation (Wang et al., 2001, Wang et al., 2004, Wang and Lufkin, 2005), does not appear to be regulated by Wnt signaling, as Hmx3 expression is not affected in Wnt1/ Wnt3a mutant otocysts (Riccomagno et al., 2005). Thus, it appears that the two families of homeobox containing transcription factors required for canal formation, Dlx and Hmx, are independently regulated, possibly by distinct extrinsic signals.

\section{Crista and canal formation}

The semicircular canals are derived from the dorsolateral region of the otocyst, where DIx and $\mathrm{Hmx}$ family of transcription factors are expressed. Although both $D / x$ and $H m x$ are largely not expressed in the presumptive cristae, they are required for crista formation, possibly by regulating proper expression of cristaspecific genes. For example, the expression domains of Bmp4, which is a robust marker for the presumptive cristae, are disorganized or absent in D/xand Hmxmutants (Wang et al., 2001, Merlo et al., 2002, Wang et al., 2004, Wang and Lufkin, 2005, Robledo and Lufkin, 2006).

The expression of Bmp4 in the presumptive cristae is conserved among many species, including zebrafish, frogs, chicken and mice (Hemmati-Brivanlou and Thomsen, 1995, Wu and Oh, 1996, Morsli et al., 1998, Mowbray et al., 2001). Inner ear phenotypes resulted from ectopic expression of a BMP antago- 
nist, Noggin, in chicken inner ears show that BMPs are required for proper formation of both cristae and canals (Chang et al., 1999, Gerlach et al., 2000). These results are supported by an inner ear specific knockout of Bmp4in mice (unpublished results, Chang et al. ). Other genes that are expressed in the presumptive cristae and have been shown to be required for both crista and canal formation are Sox2, Jagged1 and Fgf10 (Pauley et al., 2003, Kiernan et al., 2005, Brooker et al., 2006, Kiernan et al., 2006).

Several lines of evidence suggest that the formation of cristae and their associated canals are related. For example, Fgf10 is expressed in the presumptive cristae, yet Fgf10 knockout inner ears show defective cristae as well as absence of all three canals (Pauley et al., 2003), suggesting that the Fgf10 expressed in the presumptive cristae is also required for canal formation (Pauley et al., 2003). Consistently, gain- and loss-of FGF functions in the developing chicken inner ears show that FGFs indeed promote canal formation (Chang et al., 2004a). Fate mapping studies of the canal pouch using Dil identified a 'canal genesis zone' that lie adjacent to the presumptive crista (Chang et al., 2004a). Cells in the canal genesis zones give rise to a majority of cells in the canals and some of the cells in the common crus. The formation of the canal genesis zones appears to involve activation of Bmp2 expression through Fgf signaling emanating from the adjacent presumptive cristae (Chang et al., 2004a). It is not clear how Sox2 (a transcription factor) and Jagged1 (a Notch ligand) mediate canal formation. Their requirement for canal formation could be indirect, by maintaining the integrity of the sensory tissue and thus a supply of secreted canal-promoting molecules such as Bmp4 and Fgf10.

\section{Resorption and common crus formation}

The common crus is a structure that forms as a result of the resorption process in the vertical canal pouch (Figure 1 and 4). Therefore, Fgfg and Netrin1 that have been implicated in the normal resorption process within the canal pouch are also required for common crus formation. In Fgfg and Netrin 1 knockout mutants, the epithelia in the center region of each prospective canal fail to come together to form a fusion plate, resulting in the absence of resorption and failure of common crus formation (Salminen et al., 2000, Pirvola et al., 2004). While the resorption process regulates common crus formation, accumulating evidence suggests that additional mechanisms may be involved. Mis-expression experiments in chicken suggest that the center

\section{E10.75}
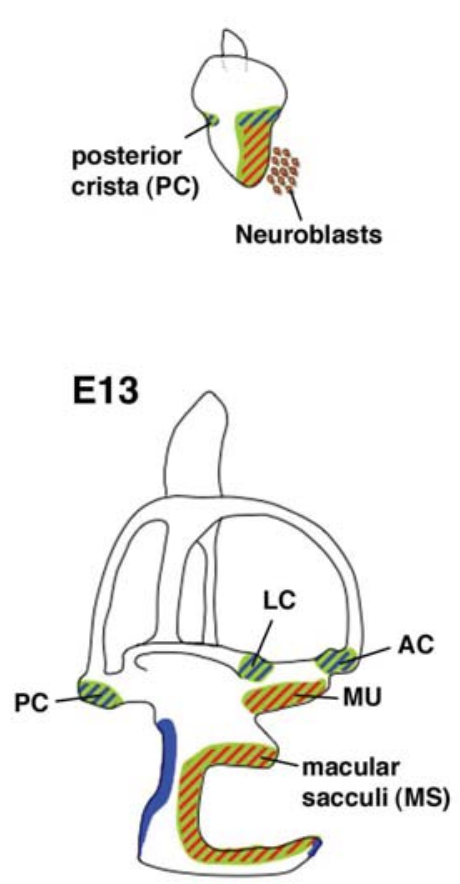

E11.5
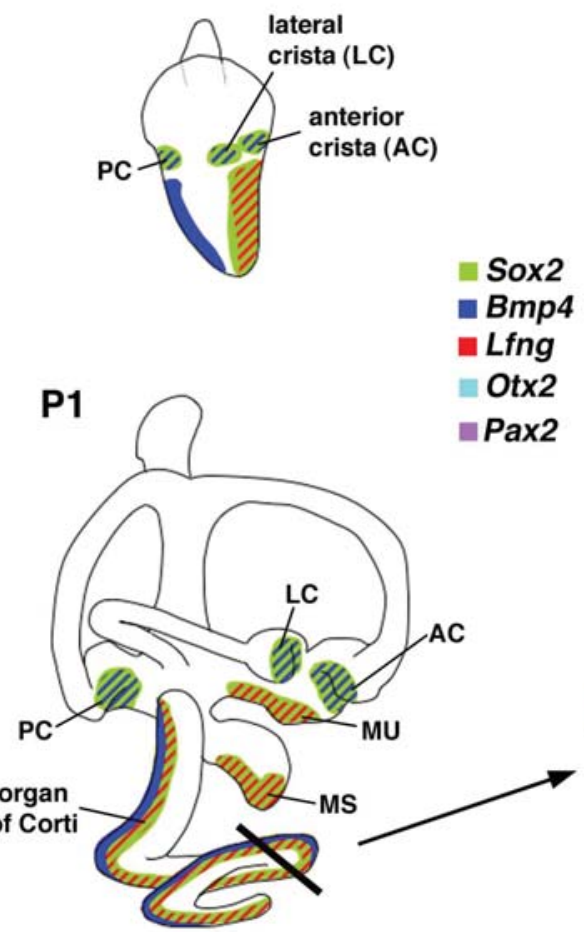

E12

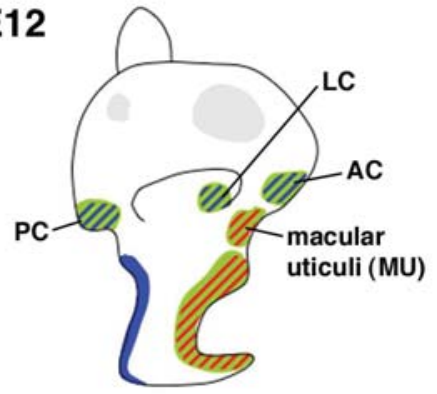

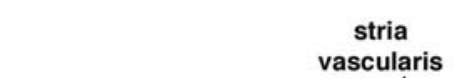

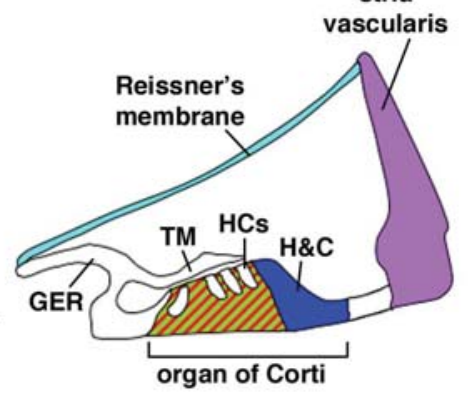

Fig. 3. Sensory organ formation in the mouse inner ear. At E10.75, Bmp4 and Lfng are expressed in subsets of cells within the larger Sox2-positive, neurosensory domain of the otocyst. The Bmp4 expression domains, forming a Bmp4-positive anterior streak and a posterior focus, are associated with the three presumptive cristae. Lfng is expressed broadly in the anterior ventral region of the otocyst, associated with the macula utriculi, macula sacculi, organ of Corti and where neuroblasts delaminate. By E11.5, the presumptive anterior and lateral cristae are separate entities. Bmp4 is also expressed in the non-sensory region of the developing cochlear duct. ByE12, the broad Lfng expression domain splits into two distinct regions: a dorsal, macula utriculi and a ventral domain that consists of the macula sacculi and organ of Corti, which become distinct entities by E13. Lfng is also expressed in the three cristae by $\mathrm{E} 12$ (not shown). A cross-section view of the organ of Corti at P1 shows that Sox 2 and Lfng are down-regulated in sensory hair cells but strongly expressed in supporting cells. Abbreviations: GER, greater epithelial ridge; TM, tectorial membrane; HCs, hair cells; $H \& C$, Hensen's and Claudius' cells. 
region of the canal pouch that develops into the common crus requires low levels of BMPs and FGFs (Chang et al., 1999, Chang et al., 2004a).

\section{Preferential requirements for specific cristae and canals}

The only known gene that is exclusively expressed in a specific crista or canal is Otx1. Otx1 is transiently expressed in the presumptive lateral crista and canal and is required for the formation of these structures (Morsli et al., 1999). However, phenotypic analyses of mouse mutants indicate that many genes are differentially required among the three cristae and canals, even though their expression patterns appear ubiquitous. For example, Fgf10 is expressed in all three cristae, but only the posterior crista and not the anterior and lateral cristae is affected when Fgf10 is knocked out (Pauley et al., 2003). In addition, functional redundancy among genes within the same family is evident since the inner ear phenotypes in D/x5/D/×6 and Hmx2/ $H m \times 3$ double mutants are much more severe than those in $D / x 5$ and Hmx2or Hmx3single mutants (Wang etal., 2001, Merlo etal., 2002, Wang et al., 2004, Wang and Lufkin, 2005, Robledo and Lufkin, 2006).

Recent studies from Shh-/-and Gli3-/-inner ears indicate that although Shh and Gli3are acting in the same signaling cascade, these genes are required at different stages of canal formation (Bok et al., 2007). In both mutants, the lateral canal is missing. However, onsets of the lateral canal defect are different, such that the lateral canal pouch fails to develop in the absence of Gli3, whereas in Shh-/- mutants, the lateral canal pouch appears normal but fails to develop into a canal (Bok et al., 2007).

Perhaps, a more interesting vestibular canal phenotype is the one displayed in Foxg1-/-mutants (Pauley et al., 2006). In these mutants, the anterior and lateral cristae are replaced by a single crista that is associated with both the anterior and lateral canals. It is not clear whether this single crista represents two presumptive cristae that fail to separate or separation occurs normally but one of them degenerates shortly after. Regardless of the cause of this malformation, this phenotype represents an early patterning defect during crista formation.

\section{Utricle and Saccule formation}

\section{Relationship between cochleovestibularganglion and the macula of the utricle}

Accumulating evidence suggest that the macula of the utricle shares a common origin with neurons of the CVG. This was first demonstrated by cell lineage tracing experiments in chicken using replication incompetent retrovirus (Satoh and Fekete, 2005). While dispersion of clonally related cells was limited when epitopetagged viruses were delivered at the otic cup or otocyst stage, there were clear examples of clonal progeny giving rise to sensory cells within the macula of the utricle and neurons of the vestibular and auditory ganglia. In addition, results from several mouse mutant studies also support the idea of a common origin between the macula of the utricle and CVG. It has been proposed that the Helix-loop-helix transcription factor, Ngn1, which is expressed in the neurosensory precursor cells in the otic epithelium and the delaminated neurons, is required for neuronal specification (Ma et al., 1998, Ma et al., 2000). In Ngn1 knockout mice, the CVG is absent, but the size of the presumptive macula utriculi is initially larger than normal (Matei et al., 2005). While a number of scenarios could explain for the increase in the size of the presumptive macula utriculi, an attractive hypothesis in light of the common origin model is that in the absence of $\mathrm{Ngn1}$, the prospective neuroblasts fail to delaminate from the otic epithelium and contribute instead to the sensory region of the utricle. The failure of the macula utriculi to maintain its increased size at later stages in the $\mathrm{Ngn} 1$ mutants is attributed to the premature differentiation of the sensory cells (Matei et al., 2005).

The Notch signaling pathway has long been implicated in the specification of neural, hair cell and supporting cell fates of the inner ear (Fekete and Wu, 2002, Kelley, 2006). The lack of one of the ligands for the Notch receptors, Delta1, causes an increase in the size of CVG, presumably due to a failure to inhibit neural fate via lateral inhibition (Brooker et al., 2006). Interestingly, in these mutants, the size of the macula utriculi is also reduced. This is an expected result if the macula utriculi indeed shares a common origin with the CVG and thus, in the absence of Delta 1, more cells are shunted towards the neural fate. In addition, when the neurosensory domain is expanded such as in the case of Tbx $1 \%$ mutants, the resulting macula utriculi are larger, presumably due to an expanded neurosensory domain at an earlier stage (Raft et al., 2004). Taken together, these observations suggest that a subpopulation of the cells within the neurosensory domain delaminates to form the neuroblasts under the regulation of $\mathrm{Ngn} 1$ and the Notch signaling pathways. Then, cells that remain in the neurosensory domain develop into sensory hair cells and supporting cells of the macula utriculi.

\section{Formation of the saccule}

The macula sacculi is thought to derive from the same $L f n g$ positive, neurosensory region that gives rise to the macula utriculi, neurons of the CVG and the organ of Corti (Morsli et al., 1998). Therefore, the macula of the saccule may also share a common origin with the neurogenic region. In Delta 1-/-mutants, the size of the macula sacculi is smaller, similar to the observed smaller macula utriculi, supporting the notion that the origins of the macula sacculi and CVG may also be related (Brooker et al., 2006). In contrast, while the common origin hypothesis would predict a comparable increase in the size of the presumptive saccule as the utricle in the Ngn1-/- mutants, no presumptive macula sacculi is evident at early stages and only a small saccule is present by embryonic day 18.5 (Ma et al., 2000, Matei et al., 2005). Many scenarios could account for these results. The increased cell death observed in the presumptive saccular region in the Ngn1 -/-mutants could account for the initial absence of this sensory patch (personal communication, Steven Raft). In addition, the switch in cell fates as a result of the lack of $\mathrm{Ngn} 1$ could cause a delay in the normal separation of the two presumptive maculae resulting in the recovery of a small saccule at later stages (Ma et al., 2000, Matei et al., 2005).

\section{Relationship between the utricle and saccule}

In mice, based on the expression pattern of $L f n g$, the macula utriculi is a distinct entity by embryonic day 12 , whereas the macula sacculi is not a distinct structure until embryonic day 13 (Figure 3) (Morsli et al., 1998). Little is known about how each sensory patch splits off from others during inner ear development. Several knockout mice such as $H m \times 2, H m x 3, O t \times 1$ and Otx2 
show incomplete separation of the two maculae (Morsli et al., 1999, Fritzsch et al., 2001, Wang et al., 2004). Each of these genes is expressed in the non-sensory region of the utricle and saccule, suggesting that the surrounding non-sensory tissues play a role in separating presumptive sensory patches. Interestingly, knockdown of otx 1 expression in zebrafish causes failure of the two maculae to separate, similar to the phenotypes described for the Otx 1 null mutants. The inner ear morphology of these ot 1 knockdown zebrafish embryos also resembles the lamprey inner ears, which do not express otx1 (Hammond and Whitfield, 2006). Thus, it has been proposed that the acquisition of Otx 1expression is an important molecular distinction between agnathans and gnathostomes (Hammond and Whitfield, 2006).

So far, Gata3 is the only known gene that is preferentially expressed in the utricle and not in the saccule (Karis et al., 2001). However, the formations of both utricle and saccule are affected in Gata3 knockout inner ears (Karis et al., 2001, Lillevali et al., 2006). Defects in both utricle and saccule are also present in several other knockout mice, such as Eya1, Six1 and Shh (Riccomagno et al., 2002, Ozaki et al., 2004, Lillevali et al., 2006, Zou et al., 2006). There are also mutants in which saccular formation is affected, but the utricle is relatively normal. Pax2and Otx 1 null mutants are good examples (Morsli et al., 1999, Burton et al., 2004). However, there are no existing mutants, in which an intact saccule forms in the absence of a utricle, suggesting that the utricle may dictate or regulate the formation of the saccule.

\section{Cochlear patterning}

The vertebrate cochlea is a specialized organ responsible for relaying sounds to the brain by converting mechanical sound energy into electrical energy. The mammalian cochlear duct is a coiled structure resembling the shape of a snail, while the avian cochlear duct (basilar papilla) is relatively straight. In mice, the cochlear duct first initiates from a postero-lateral region of the otocyst and descends ventro-medially forming an L-shaped organ (a half turn) by embryonic day 12 (Figure 1). Then, the cochlear duct continues to extend and coil with the mature mouse structure consisting of one and three quarter turns. Similar to other mammals, the mouse cochlear duct is tonotopically organized such that the base of the cochlear duct is most sensitive to high frequency sounds and the apical region to low frequency sounds (Davis, 2003).

The number of coils in the cochlear duct is different among various species. The relationship between the number of coils of the cochlear duct and its functions in sound conduction is not clear, although a recent mathematical model suggests a possible relationship between the radius of the cochlear spirals and the ability to detect low frequency sounds (West, 1985, Manoussaki etal., 2006). Undoubtedly, the patterning of this structure remains one of the most fascinating questions about inner ear development. What are the signaling molecules that regulate cochlear duct growth and patterning? Convergent extension of cellular movements that occur during gastrulation may also take place during cochlear duct formation (Chen et al., 2002, Keller, 2002, Mansour and Schoenwolf, 2005, Jones and Chen, 2007). Accumulating evidence suggest that the primordial organ of Corti domain within the cochlear duct starts out thick and wide and, through cellular intercalation radially and extension along the proximal distal axis of the cochlear duct, give rise to the final pattern of four rows of hair cells (McKenzie et al., 2004, Wang et al., 2005). Genes within the planar cell polarity pathway such as Dishevelled, Vangl2and Celsr1 are thought to be involved in this process (Wang et al., 2005, Jones and Chen, 2007). Readers are referred to other reviews in this issue for further discussion on this topic.

Furthermore, recent inner ear analyses of various compound mutants associated with Shh signaling pathway suggests that distal and proximal regions of the cochlear duct, which detect different ranges of sound frequencies, are patterned by different molecular mechanisms (Bok et al., 2007). It was demonstrated that the distal cochlear region requires robust Gli activator function mediated by high levels of Shh signaling, whereas the proximal region of the cochlear duct will form with relatively low level of Shh that is sufficient to remove Gli3 repressor function (Bok et al., 2007).

In cross section, the cochlear duct is triangular in shape and has three walls: 1) the floor, which consists of the sensory component, the organ of Corti and the greater epithelial ridge; 2) the thin medial wall made up of the Reissner's membrane; and 3) the lateral wall, which consists of the stria vascularis (responsible for maintaining the endocochlear potential within the cochlear duct) (Figure 3). Interestingly, mutations affecting normal cellular differentiation and organization of any of these walls of the cochlear duct result in abnormal patterning of the cochlear duct (see below). For example, when Otx2, which is expressed in the Reissner's membrane, is knocked out, cochlear duct formation is abnormal (Morsli et al., 1999). In addition, Pax2, expressed in the stria vascularis of the lateral wall of the cochlear duct, is also required for normal cochlear duct outgrowth (Burton et al., 2004).

\section{Sensory component in cochlear patterning}

Several genes required for proper patterning of the organ of Corti are also important for normal cochlear duct outgrowth. For example, in $Y_{s b}$ or $L c c$ mutants, in which Sox2 expression is affected, both the organ of Corti and the cochlear duct are malformed (Kiernan et al., 2005). In addition, Jagged1, which is expressed in the presumptive sensory regions and encodes a ligand for the Notch signaling pathway, also results in malformed organ of Corti and shortened cochlear duct when this gene is knocked out in mice (Brooker et al., 2006, Kiernan et al., 2006). Similarly, Foxg1, a transcription factor expressed in the organ of Corti and the greater epithelial ridge, has been shown to be required for proper organization of the hair cells as well as normal cochlear duct outgrowth (Pauley et al., 2006). These results suggest that proper patterning of the sensory component of the cochlea, the organ of Corti, is important for normal outgrowth of the cochlear duct and further support the idea that the sensory component of an inner ear structure regulates the formation of its non-sensory component, similar to what has been described for crista and semicircular canal formation (Chang et al., 2004a).

However, not all genes that affect proper formation of the organ of Corti result in a malformed cochlear duct phenotype. An example is Sprouty2. In Spry2-/- mutants, the cochlear duct morphology is normal despite a cell fate change from a Deiters' cell to a pillar cell in the organ of Corti (Shim et al., 2005). A possible explanation for this apparent exception may be the relatively late requirement of Spry2 function, possibly at a time when the sensory component is no longer required for the gross 


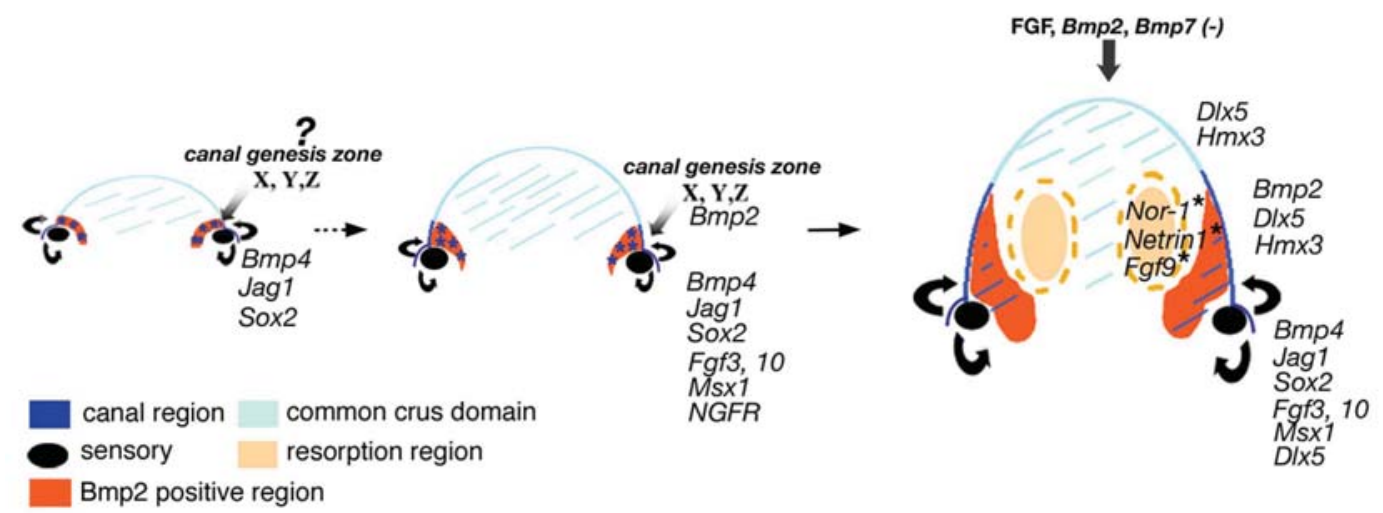

B

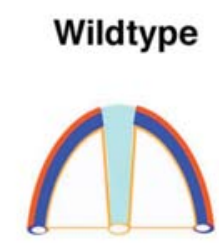

Mutants

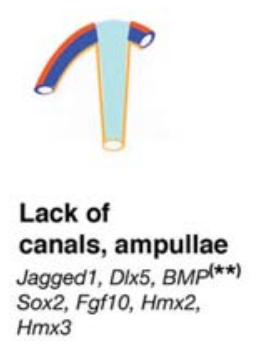

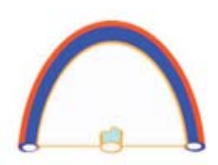

Lack of common crus Gbx2

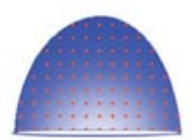

Non-resorption Fgf9, Netrin1

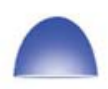

Rudimentary vestibular apparatus Wnt1/Wnt3a, Gata3, Eya1 $H m \times 2 / H m \times 3, D l \times 5 / D / x 6$ Gbx2

Fig. 4. A schematic diagram of semicircular canal and common crus formation. (A) Progression of chicken canal pouch development from E2.5 to E6. Signaling molecules such as Bmp4 and Fgfs are secreted from the presumptive cristae (black color) to induce canal genesis zones (blue stars) that express Bmp2 and potentially other factors ( $X, Y$ and Z). Cells from these canal genesis zones (blue color) contribute to the majority of cells in the canals and some of the cells within the common crus (not shown). Two resorption domains (light yellow color) express Netrin1, Nor-1 and Fgf9 in the epithelia. The center region of the canal pouch (light blue color) that develops into the common crus does not express Bmp2 or Bmp7 and receives low levels of Fgf signaling. $\mathrm{Hm} \times 2, \mathrm{Hm} \times 3$ and DIx5 are ubiquitously expressed in the canal pouch. (B) Examples of some typical canal phenotypes among various knockout mouse mutants. Genes responsible for causing each phenotype are in italic. Single asterisk represents data obtained from mouse and double asterisks represent data from chicken.

morphogenesis of the cochlear duct.

Even though the basilar papilla in chicken does not coil like the cochlear duct in mammals, the two structures have similar patterning in the proximal region, both emerging from a posterior lateral region of the developing otocyst and descending in a ventro-anterior direction. Interestingly, the gross patterning of the basilar papilla is dependent on the AP axial identity of the neurosensory domain. When the AP axis of the chicken otocyst is reversed in ovo at a time when the AP axis of the neurosensory domain is committed, the AP orientation of the cochlear duct is also reversed, originating from an antero-lateral region of the otocyst (Wu et al., 1998). These results suggest that the AP orientation of the neurosensory domain of the otocyst dictates not only the position of the cochlear sensory component but also the global patterning of the entire cochlear duct.

\section{Non-sensory component in cochlear patterning}

Genes encoding transcription factors such as Otx1 and Otx2 are expressed in the otic epithelium of the developing cochlea, yet they are not expressed in the presumptive sensory domain nor do they appear to be required for the organ of Corti formation (Morsli et al., 1999). However, targeted deletions of these genes result in abnormal cochlear duct outgrowth and coiling, indicating the importance of these genes in proper patterning of the cochlear duct (Morsli etal., 1999, Cantos etal., 2000). Although not directly examined in the inner ear, Otx 1 and Otx2have been shown to be required for normal cell proliferation and regionalization in brain development (Simeone et al., 2002).

PAX2, a paired-box transcription factor, is associated with renal-coloboma syndrome in humans (Sanyanusin et al., 1995, Schimmenti et al., 1997). Mild neurosensory hearing loss has been reported as one of the defects associated with this syndrome (Schimmenti et al., 1997). Inner ear analyses of Pax2-/mutants reveal an early requirement of Pax2 in cochlear duct outgrowth (Torres et al., 1996, Burton et al., 2004). Even though Pax2 is expressed in sensory hair cells and its expression domain overlaps with the neurosensory domain at early otocyst stages, its expression in the developing cochlear duct is mostly in the nonsensory domain in mice (Burton et al., 2004). Changes in gene expression profiles in Pax2-/-inner ears indicate that the cochlear outgrowth and patterning is arrested at an early stage of cochlear development, possibly due to a decrease in cell proliferation and an increase in cell death in the domains that normally express Pax2in the developing cochlea (Burton et al., 2004). It is not clear 
how these phenotypes in Pax2 null embryos relates to deafness in renal-coloboma syndrome, but it has been postulated that transcription factors expressed in the developing cochlea, including Pax2 and Otx1, may play a critical role in proper extension, orientation and coiling of the cochlear duct, by governing differential proliferation and growth within the various regions of the cochlea (Burton et al., 2004).

\section{Epithelial-mesenchymal interactions in cochlear patterning}

The mesenchymal tissues surrounding the developing inner ear develop into the otic capsule or bony labyrinth. Since the bony labyrinth closely follows the shape of the membranous labyrinth of the inner ear, intimate cellular interactions must exist between the otic epithelium and its surrounding mesenchyme during development. Therefore, any failure of proper epithelial-mesenchymal interactions could affect the patterning and morphogenesis of both labyrinths. Inner ear analyses of Brn-4/Pou3f4knockout mutants provide a clear example of the importance of these interactions (Phippard et al., 1999). Brn-4/Pou3f4 is expressed in the mesenchymal tissues surrounding the developing inner ear but not within the otic epithelium itself. However, Brn-4/Pou3f4 knockout mice show defects in inner ear morphogenesis, including a reduction in the number of cochlear coils (Phippard et al., 1999). These results demonstrate that gene expression changes in the mesenchyme can cause defects in the inner ear epithelium, most likely due to abnormal epithelial-mesenchymal interactions.

Signaling from the otic epithelium also coordinates proper epithelial-mesenchymal development. For example, while the formation of the cochlear duct in Fgfg null mutants is largely normal, the lack of Fgfgexpression in the Reissner's membrane is thought to cause the defects in the Scala vestibuli observed in these mutants (Pirvola et al., 2004). Tbx 1 is expressed in both the otic epithelium and periotic mesenchyme. Tissue-specific knockout studies indicate that $T b \times 1$ in the mesenchyme is required for mesenchymal expression of Brn-4/Pou3f4 (Arnold et al., 2006). Consistent with the role of Brn-4/Pou3f4 in the cochlear development, mesenchyme-specific deletion of $T b \times 1$ causes a malformation of the cochlear duct (Xu etal., 2007). Interestingly, the periotic mesenchymal expression of Tbx1 is dependent on Shh (Riccomagno et al., 2002). Therefore, a molecular pathway of Shh-Tbx1-Brn-4 in the periotic mesenchyme may be involved in mediating normal cochlear duct patterning.

\section{Genes not expressed in the cochlear epithelial and mesenchymal regions}

Mutations of some genes, which are not expressed in the epithelial or mesenchymal region of the developing cochlear duct, also cause defects in cochlear patterning. One such example is $G b \times 2$, whose expression is restricted to the dorsal-medial aspect of the otocyst, yet the inner ears of Gbx2-/-mutants show various degrees of cochlear malformations as well as the vestibular defects as discussed above (Lin etal., 2005). This cochlear defect in Gbx2\%- mutants may be related to the abnormal medial expansion of the Otx2expression domain, whose normal expression in the otocyst is important for cochlear development (Morsli et al., 1999, Lin et al., 2005). Mutations of genes that are thought to be upstream of Gbx2 such as Mafb/kreisler and Hoxa1 also showed similar phenotypes (Mansour et al., 1993, Mark et al., 1993, Choo et al., 2006). As previously discussed, we attributed these cochlear defects to abnormal ML specification, which indirectly affects cochlear patterning.

Lastly, mutations resulting in abnormal differentiation of the CVG such as Ngn1-/- or NeuroD1-/-, also result in a shortened cochlear duct (Liu et al., 2000, Ma et al., 2000, Kim et al., 2001, Matei etal., 2005), suggesting that signals from the CVG may also play a role in cochlear development. In summary, coordination of various extrinsic and intrinsic factors within and around the developing inner ear is critical for proper development of the coiled mammalian cochlear duct.

\section{Conclusion}

While we have categorized the phenotypes of many of the known inner ear mutants with respect to potential defects in axial and/or positional specification, there are two categories of phenotypes that are not well covered in this review. One category includes mutants with rudimentary otocyst phenotypes such as Fgfr-2(IIIb), Gata3 and Eya1 null mutants. The rudimentary state of the inner ears makes it difficult to identify axial defects, if any exists. For example, in Gata3-/-inner ears, while the neurosensory domain is abnormal, there appears to be additional cell adhesion defects that cause the separation of the dorsal and ventral domains of the otocyst (Lillevali et al., 2006). Another category of inner ear phenotypes that is beyond the scope of this review are mutants with disrupted fluid homeostasis of the inner ear. These inner ear defects are often associated with engorgement or shrinkage of the membranous labyrinth due to fluid imbalance rather than problems in morphogenesis (Cowan et al., 2000, Everett et al., 2001, Chang et al., 2004b, Dravis et al., 2007). In summary, the continual discoveries of inductive signals and their downstream cascades of molecule events for inner ear formation will decode the formation of this complex organ and pave the way for design of strategies to improve hearing and vestibular disorders.

\section{Acknowledgements}

We thank Dr. Steven Raft for sharing his manuscript prior to publication and Drs. Susan Sullivan and Robert Morell for critical reading of the manuscript. This work was supported by the NIDCD Intramural Program.

\section{References}

ALSINA, B., ABELLO, G., ULLOA, E., HENRIQUE, D., PUJADES, C. and GIRALDEZ, $F$. (2004). FGF signaling is required for determination of otic neuroblasts in the chick embryo. Dev Bio/267: 119-34.

ARNOLD, J.S., BRAUNSTEIN, E.M., OHYAMA, T., GROVES, A.K., ADAMS, J.C., BROWN, M.C. and MORROW, B.E. (2006). Tissue-specific roles of Tbx1 in the development of the outer, middle and inner ear, defective in 22q11DS patients. Hum Mol Genet 15: 1629-39.

BOK, J., BRONNER-FRASER, M. and WU, D.K. (2005). Role of the hindbrain in dorsoventral but not anteroposterior axial specification of the inner ear. Deve/opment 132: 2115-24.

BOK, J., DOLSON, D.K., HILL, P., RUTHER, U., EPSTEIN, D.J. and WU, D.K. (2007). Opposing gradients of Gli repressor and activators mediate Shh signaling along the dorsoventral axis of the inner ear. Development 134: 171322.

BRIGANDE, J.V., ITEN, L.E. and FEKETE, D.M. (2000a). A fate map of chick otic cup closure reveals lineage boundaries in the dorsal otocyst. Dev Bio/227: 25670.

BRIGANDE, J.V., KIERNAN, A.E., GAO, X., ITEN, L.E. and FEKETE, D.M. (2000b). 
Molecular genetics of pattern formation in the inner ear: do compartment boundaries play a role? Proc Nat/ Acad Sci USA 97: 11700-6.

BROOKER, R., HOZUMI, K. and LEWIS, J. (2006). Notch ligands with contrasting functions: Jagged1 and Delta1 in the mouse inner ear. Development 133: 127786.

BURTON, Q., COLE, L.K., MULHEISEN, M., CHANG, W. and WU, D.K. (2004). The role of Pax2 in mouse inner ear development. Dev Bio/272: 161-75.

CANTOS, R., COLE, L.K., ACAMPORA, D., SIMEONE, A. and WU, D.K. (2000). Patterning of the mammalian cochlea. Proc Nat/ Acad Sci USA 97: 11707-13.

CHANG, W., BRIGANDE, J.V., FEKETE, D.M. and WU, D.K. (2004a). The development of semicircular canals in the inner ear: role of FGFs in sensory cristae. Development 131: 4201-11.

CHANG, W., COLE, L.K., CANTOS, R. and WU, D.K. (2004b). Molecular genetics of Vestibular Organ Development. In The Vestibular System, (ed. HIGHSTEIN, S. M.FAY, R. R. and POPPER, A. N.). Springer, New York, pp.11-56.

CHANG, W., NUNES, F.D., DE JESUS-ESCOBAR, J.M., HARLAND, R. and WU, D.K. (1999). Ectopic noggin blocks sensory and nonsensory organ morphogenesis in the chicken inner ear. Dev Bio/216: 369-81.

CHOO, D., WARD, J., REECE, A., DOU, H., LIN, Z. and GREINWALD, J. (2006). Molecular mechanisms underlying inner ear patterning defects in kreisler mutants. Dev Bio/289: 308-17.

COLE, L.K., LE ROUX, I., NUNES, F., LAUFER, E., LEWIS, J. and WU, D.K. (2000). Sensory organ generation in the chicken inner ear: contributions of bone morphogenetic protein 4, serrate1 and lunatic fringe. J Comp Neuro/424: 50920.

COWAN, C.A., YOKOYAMA, N., BIANCHI, L.M., HENKEMEYER, M. and FRITZSCH, B. (2000). EphB2 guides axons at the midline and is necessary for normal vestibular function. Neuron 26: 417-30.

DAVIS, R.L. (2003). Gradients of neurotrophins, ion channels and tuning in the cochlea. Neuroscientist 9: 311-6.

DEOL, M.S. (1964). The Abnormalities of the Inner Ear in Kreisler Mice. J Embryol Exp Morpho/12: 475-90.

DRAVIS, C., WU, T., CHUMLEY, M.J., YOKOYAMA, N., WEI, S., WU, D.K., MARCUS, D.C. and HENKEMEYER, M. (2007). EphB2 and ephrin-B2 regulate the ionic homeostasis of vestibular endolymph. Hear Res 223: 93-104.

EVERETT, L.A., BELYANTSEVA, I.A., NOBEN-TRAUTH, K., CANTOS, R., CHEN, A., THAKKAR, S.I., HOOGSTRATEN-MILLER, S.L., KACHAR, B., WU, D.K. and GREEN, E.D. (2001). Targeted disruption of mouse Pds provides insight about the inner-ear defects encountered in Pendred syndrome. Hum Mol Genet 10: 153-61.

FEKETE, D.M. and WU, D.K. (2002). Revisiting cell fate specification in the inner ear. Curr Opin Neurobiol 12: 35-42.

FRASER, S., KEYNES, R. and LUMSDEN, A. (1990). Segmentation in the chick embryo hindbrain is defined by cell lineage restrictions. Nature 344: 431-5.

FRITZSCH, B., SIGNORE, M. and SIMEONE, A. (2001). Otx1 null mutant mice show partial segregation of sensory epithelia comparable to lamprey ears. Dev Genes Evo/211: 388-96.

GERLACH, L.M., HUTSON, M.R., GERMILLER, J.A., NGUYEN-LUU, D., VICTOR, J.C. and BARALD, K.F. (2000). Addition of the BMP4 antagonist, noggin, disrupts avian inner ear development. Development 127: 45-54.

GRAHAM, A., BEGBIE, J. and MCGONNELL, I. (2004). Significance of the cranial neural crest. Dev Dyn 229: 5-13.

GROVES, A.K. and BRONNER-FRASER, M. (2000). Competence, specification and commitment in otic placode induction. Development 127: 3489-99.

HAMMOND, K.L. and WHITFIELD, T.T. (2006). The developing lamprey ear closely resembles the zebrafish otic vesicle: otx 1 expression can account for all major patterning differences. Development 133: 1347-57.

HARRISON, R.G. (1936). Relations of Symmetry in the Developing Ear of Amblystoma punctatum. Proc Natl Acad Sci USA 22: 238-247.

HEMMATI-BRIVANLOU, A. and THOMSEN, G.H. (1995). Ventral mesodermal patterning in Xenopus embryos: expression patterns and activities of BMP-2 and BMP-4. Dev Genet 17: 78-89.

HIDALGO-SANCHEZ, M., ALVARADO-MALLART, R. and ALVAREZ, I.S. (2000).
Pax2, Otx2, Gbx2 and Fgf8 expression in early otic vesicle development. Mech Dev 95: 225-9.

IKEYA, M., LEE, S.M., JOHNSON, J.E., MCMAHON, A.P. and TAKADA, S. (1997). Wnt signalling required for expansion of neural crest and CNS progenitors. Nature 389: 966-70.

INGHAM, P.W. and MCMAHON, A.P. (2001). Hedgehog signaling in animal development: paradigms and principles. Genes Dev 15: 3059-87.

JONES, C. and CHEN, P. (2007). Planar cell polarity signaling in vertebrates. Bioessays 29: 120-32.

KARIS, A., PATA, I., VAN DOORNINCK, J.H., GROSVELD, F., DE ZEEUW, C.I., DE CAPRONA, D. and FRITZSCH, B. (2001). Transcription factor GATA-3 alters pathway selection of olivocochlear neurons and affects morphogenesis of the ear. J Comp Neuro/429: 615-30.

KELLEY, M.W. (2006). Regulation of cell fate in the sensory epithelia of the inner ear. Nat Rev Neurosci 7: 837-49.

KIERNAN, A.E., PELLING, A.L., LEUNG, K.K., TANG, A.S., BELL, D.M., TEASE, C., LOVELL-BADGE, R., STEEL, K.P. and CHEAH, K.S. (2005). Sox2 is required for sensory organ development in the mammalian inner ear. Nature 434: 1031-5.

KIERNAN, A.E., STEEL, K.P. and FEKETE, D.M. (2002). Development of the mouse inner ear. In Mouse Development: Patterning, Morphogenesis and Organogensis, (ed. ROSSANT, J. and TAM, P. P. L.). Academic Press, San Diego, pp.539-566.

KIERNAN, A.E., XU, J. and GRIDLEY, T. (2006). The Notch Ligand JAG1 Is Required for Sensory Progenitor Development in the Mammalian Inner Ear. PLOS Genet 2: e4.

KIM, W.Y., FRITZSCH, B., SERLS, A., BAKEL, L.A., HUANG, E.J., REICHARDT, L.F., BARTH, D.S. and LEE, J.E. (2001). NeuroD-null mice are deaf due to a severe loss of the inner ear sensory neurons during development. Development 128: 417-26.

LADHER, R.K., WRIGHT, T.J., MOON, A.M., MANSOUR, S.L. and SCHOENWOLF, G.C. (2005). FGF8 initiates inner ear induction in chick and mouse. Genes Dev 19: 603-13.

LEE, K.J. and JESSELL, T.M. (1999). The specification of dorsal cell fates in the vertebrate central nervous system. Annu Rev Neurosci22: 261-94.

LIEM, K.F., JR., JESSELL, T.M. and BRISCOE, J. (2000). Regulation of the neural patterning activity of sonic hedgehog by secreted BMP inhibitors expressed by notochord and somites. Development 127: 4855-66.

LIEM, K.F., JR., TREMML, G., ROELINK, H. and JESSELL, T.M. (1995). Dorsal differentiation of neural plate cells induced by BMP-mediated signals from epidermal ectoderm. Cel/82: 969-79.

LILLEVALI, K., HAUGAS, M., MATILAINEN, T., PUSSINEN, C., KARIS, A. and SALMINEN, M. (2006). Gata3 is required for early morphogenesis and Fgf10 expression during otic development. Mech Dev.

LIN, Z., CANTOS, R., PATENTE, M. and WU, D.K. (2005). Gbx2 is required for the morphogenesis of the mouse inner ear: a downstream candidate of hindbrain signaling. Development 132: 2309-18.

LIU, M., PEREIRA, F.A., PRICE, S.D., CHU, M.J., SHOPE, C., HIMES, D. EATOCK, R.A., BROWNELL, W.E., LYSAKOWSKI, A. and TSAI, M.J. (2000). Essential role of BETA2/NeuroD1 in development of the vestibular and auditory systems. Genes Dev 14: 2839-54.

LIU, W., LI, G., CHIEN, J., RAFT, S., ZHANG, H., CHIANG, C. and FRENZ, D. (2002). Sonic hedgehog regulates otic capsule chondrogenesis and inner ear development in the mouse embryo. Dev Bio/248: 240.

LUMSDEN, A. and KRUMLAUF, R. (1996). Patterning the vertebrate neuraxis Science 274: 1109-15.

MA, Q., ANDERSON, D.J. and FRITZSCH, B. (2000). Neurogenin 1 null mutant ears develop fewer, morphologically normal hair cells in smaller sensory epithelia devoid of innervation. J Assoc Res Otolaryngo/1: 129-43.

MA, Q., CHEN, Z., DEL BARCO BARRANTES, I., DE LA POMPA, J.L. and ANDERSON, D.J. (1998). neurogenin1 is essential for the determination of neuronal precursors for proximal cranial sensory ganglia. Neuron 20: 469-82.

MAKLAD, A. and FRITZSCH, B. (2003). Development of vestibular afferent projections into the hindbrain and their central targets. Brain Res Bul/60: 497-510. 
MANOUSSAKI, D., DIMITRIADIS, E.K. and CHADWICK, R.S. (2006). Cochlea's graded curvature effect on low frequency waves. Phys Rev Lett 96: 088701.

MANSOUR, S.L., GODDARD, J.M. and CAPECCHI, M.R. (1993). Mice homozygous for a targeted disruption of the proto-oncogene int-2 have developmental defects in the tail and inner ear. Development 117: 13-28.

MARK, M., LUFKIN, T., VONESCH, J.L., RUBERTE, E., OLIVO, J.C., DOLLE, P., GORRY, P., LUMSDEN, A. and CHAMBON, P. (1993). Two rhombomeres are altered in Hoxa-1 mutant mice. Development 119: 319-38.

MATEI, V., PAULEY, S., KAING, S., ROWITCH, D., BEISEL, K.W., MORRIS, K., FENG, F., JONES, K., LEE, J. and FRITZSCH, B. (2005). Smaller inner ear sensory epithelia in Neurog1 null mice are related to earlier hair cell cycle exit. Dev Dyn.

MCKAY, I.J., LEWIS, J. and LUMSDEN, A. (1996). The role of FGF-3 in early inner ear development: an analysis in normal and kreisler mutant mice. Dev Bio/174: 370-8.

MCKENZIE, E., KRUPIN, A. and KELLEY, M.W. (2004). Cellular growth and rearrangement during the development of the mammalian organ of Corti. Dev Dyn 229: 802-12.

MERLO, G.R., PALEARI, L., MANTERO, S., ZEREGA, B., ADAMSKA, M., RINKWITZ, S., BOBER, E. and LEVI, G. (2002). The DIx5 homeobox gene is essential for vestibular morphogenesis in the mouse embryo through a BMP4mediated pathway. Dev Bio/248: 157-69.

MORSLI, H., CHOO, D., RYAN, A., JOHNSON, R. and WU, D.K. (1998). Development of the mouse inner ear and origin of its sensory organs. J Neurosci 18: 3327-35.

MORSLI, H., TUORTO, F., CHOO, D., POSTIGLIONE, M.P., SIMEONE, A. and WU, D.K. (1999). Otx1 and Otx2 activities are required for the normal development of the mouse inner ear. Development 126: 2335-43.

MOWBRAY, C., HAMMERSCHMIDT, M. and WHITFIELD, T.T. (2001). Expression of BMP signalling pathway members in the developing zebrafish inner ear and lateral line. Mech Dev 108: 179-84.

MYAT, A., HENRIQUE, D., ISH-HOROWICZ, D. and LEWIS, J. (1996). A chick homologue of Serrate and its relationship with Notch and Delta homologues during central neurogenesis. Dev Bio/174: 233-47.

NEVES, J., KAMAID, A., ALSINA, B. and GIRALDEZ, F. (2007). Differential expression of Sox2 and Sox3 in neuronal and sensory progenitors of the developing inner ear of the chick. $J$ Comp Neuro/503: 487-500.

NORAMLY, S. and GRAINGER, R.M. (2002). Determination of the embryonic inner ear. J Neurobio/53: 100-28.

OZAKI, H., NAKAMURA, K., FUNAHASHI, J., IKEDA, K., YAMADA, G., TOKANO, H., OKAMURA, H.O., KITAMURA, K., MUTO, S., KOTAKI, H. et al. (2004). Six1 controls patterning of the mouse otic vesicle. Development 131: 551-62.

PATTEN, I. and PLACZEK, M. (2002). Opponent activities of Shh and BMP signaling during floor plate induction in vivo. Curr Bio/12: 47-52.

PAULEY, S., LAI, E. and FRITZSCH, B. (2006). Foxg1 is required for morphogenesis and histogenesis of the mammalian inner ear. Dev Dyn.

PAULEY, S., WRIGHT, T.J., PIRVOLA, U., ORNITZ, D., BEISEL, K. and FRITZSCH, B. (2003). Expression and function of FGF10 in mammalian inner ear development. Dev Dyn 227: 203-15.

PHIPPARD, D., LU, L., LEE, D., SAUNDERS, J.C. and CRENSHAW, E.B., 3RD. (1999). Targeted mutagenesis of the POU-domain gene Brn4/Pou3f4 causes developmental defects in the inner ear. JNeurosci 19: 5980-9.

PIRVOLA, U., SPENCER-DENE, B., XING-QUN, L., KETTUNEN, P., THESLEFF, I., FRITZSCH, B., DICKSON, C. and YLIKOSKI, J. (2000). FGF/FGFR-2(IIIb) signaling is essential for inner ear morphogenesis. J Neurosci20: 6125-34.

PIRVOLA, U., ZHANG, X., MANTELA, J., ORNITZ, D.M. and YLIKOSKI, J. (2004). Fgf9 signaling regulates inner ear morphogenesis through epithelial-mesenchymal interactions. Dev Bio/273: 350-60.

RAFT, S., NOWOTSCHIN, S., LIAO, J. and MORROW, B.E. (2004). Suppression of neural fate and control of inner ear morphogenesis by Tbx1. Development 131: 1801-12.

RICCOMAGNO, M.M., MARTINU, L., MULHEISEN, M., WU, D.K. and EPSTEIN, D.J. (2002). Specification of the mammalian cochlea is dependent on Sonic hedgehog. Genes Dev 16: 2365-78.
RICCOMAGNO, M.M., TAKADA, S. and EPSTEIN, D.J. (2005). Wnt-dependent regulation of inner ear morphogenesis is balanced by the opposing and supporting roles of Shh. Genes Dev 19: 1612-23.

ROBLEDO, R.F. and LUFKIN, T. (2006). DIx5 and DIx6 homeobox genes are required for specification of the mammalian vestibular apparatus. Genesis 44: 425-37.

RUIZ I ALTABA, A., NGUYEN, V. and PALMA, V. (2003). The emergent design of the neural tube: prepattern, $\mathrm{SHH}$ morphogen and GLI code. Curr. Opin. Genet. Dev. 13: 513-21.

SALMINEN, M., MEYER, B.I., BOBER, E. and GRUSS, P. (2000). Netrin 1 is required for semicircular canal formation in the mouse inner ear. Development 127: 13-22.

SANYANUSIN, P., SCHIMMENTI, L.A., MCNOE, L.A., WARD, T.A., PIERPONT, M.E., SULLIVAN, M.J., DOBYNS, W.B. and ECCLES, M.R. (1995). Mutation of the PAX2 gene in a family with optic nerve colobomas, renal anomalies and vesicoureteral reflux. Nat Genet 9: 358-64.

SATOH, T. and FEKETE, D.M. (2005). Clonal analysis of the relationships between mechanosensory cells and the neurons that innervate them in the chicken ear Development 132: 1687-97.

SCHIMMENTI, L.A., CUNLIFFE, H.E., MCNOE, L.A., WARD, T.A., FRENCH, M.C., SHIM, H.H., ZHANG, Y.H., PROESMANS, W., LEYS, A., BYERLY, K.A. et al. (1997). Further delineation of renal-coloboma syndrome in patients with extreme variability of phenotype and identical PAX2 mutations. Am J Hum Genet 60: 869-78.

SHIM, K., MINOWADA, G., COLING, D.E. and MARTIN, G.R. (2005). Sprouty2, a mouse deafness gene, regulates cell fate decisions in the auditory sensory epithelium by antagonizing FGF signaling. Dev Ce//8: 553-64.

SIMEONE, A., PUELLES, E. and ACAMPORA, D. (2002). The Otx family. Curr Opin Genet Dev 12: 409-15.

TAJBAKHSH, S. and SPORLE, R. (1998). Somite development: constructing the vertebrate body. Cel/92: 9-16.

TORRES, M., GOMEZ-PARDO, E. and GRUSS, P. (1996). Pax2 contributes to inner ear patterning and optic nerve trajectory. Development 122: 3381-91.

TRAINOR, P.A. and KRUMLAUF, R. (2000). Patterning the cranial neural crest: hindbrain segmentation and Hox gene plasticity. Nat Rev Neurosci 1: 116-24.

VITELLI, F., VIOLA, A., MORISHIMA, M., PRAMPARO, T., BALDINI, A. and LINDSAY, E. (2003). TBX1 is required for inner ear morphogenesis. Hum Mol Genet 12: 2041-8.

WANG, J., MARK, S., ZHANG, X., QIAN, D., YOO, S.J., RADDE-GALLWITZ, K., ZHANG, Y., LIN, X., COLLAZO, A., WYNSHAW-BORIS, A. et al. (2005). Regulation of polarized extension and planar cell polarity in the cochlea by the vertebrate PCP pathway. Nat Genet 37: 980-5.

WANG, W., CHAN, E.K., BARON, S., VAN DE WATER, T. and LUFKIN, T. (2001). $\mathrm{Hm} \times 2$ homeobox gene control of murine vestibular morphogenesis. Development 128: 5017-29.

WANG, W., GRIMMER, J.F., VAN DE WATER, T.R. and LUFKIN, T. (2004). Hmx2 and $\mathrm{Hmx} 3$ homeobox genes direct development of the murine inner ear and hypothalamus and can be functionally replaced by Drosophila Hmx. Dev Ce//7: 439-53.

WANG, W. and LUFKIN, T. (2005). Hmx homeobox gene function in inner ear and nervous system cell-type specification and development. Exp Cell Res 306: 373-9.

WEST, C.D. (1985). The relationship of the spiral turns of the cochlea and the length of the basilar membrane to the range of audible frequencies in ground dwelling mammals. J Acoust Soc Am 77: 1091-101.

WU, D., NUNES, F. and CHOO, D. (1998). Axial specification for sensory organs versus non-sensory structures of the chicken inner ear. Development 125: 1120.

WU, D.K. and OH, S.H. (1996). Sensory organ generation in the chick inner ear. $J$ Neurosci 16: 6454-62.

XU, H., VIOLA, A., ZHANG, Z., GERKEN, C.P., LINDSAY-ILLINGWORTH, E.A. and BALDINI, A. (2007). Tbx1 regulates population, proliferation and cell fate determination of otic epithelial cells. Dev Bio/302: 670-82.

XU, P.X., ADAMS, J., PETERS, H., BROWN, M.C., HEANEY, S. and MAAS, R 
(1999). Eya1-deficient mice lack ears and kidneys and show abnormal apoptosis of organ primordia. Nat Genet 23: 113-7.

ZHENG, W., HUANG, L., WEI, Z.B., SILVIUS, D., TANG, B. and XU, P.X. (2003). The role of Six 1 in mammalian auditory system development. Development 130: 3989-4000.
ZOU, D., SILVIUS, D., RODRIGO-BLOMQVIST, S., ENERBACK, S. and XU, P.X. (2006). Eya1 regulates the growth of otic epithelium and interacts with Pax2 during the development of all sensory areas in the inner ear. Dev Bio/298: 43041.

Published Online: 31st August 2007

\section{Related, previously published Int. J. Dev. Biol. articles}

See our Special Issue Ear Development edited by Fernando Giraldez and Bernd Fritzsch at:

http://www.ijdb.ehu.es/web/contents.php?vol=51 \&issue=6-7

The importance of the posterior midline region for axis initiation at early stages of the avian embryo Oded Khaner

Int. J. Dev. Biol. (2007) 51: 131-137

Genetic control of dorsoventral patterning and neuroblast specification in the Drosophila Central Nervous System Guoyan Zhao, Scott R. Wheeler and James B. Skeath

Int. J. Dev. Biol. (2007) 51: 107-115

Where do we stand now? - mouse early embryo patterning meeting in Freiburg, Germany (2005)

Takashi Hiiragi, Vernadeth B. Alarcon, Toshihiko Fujimori, Sophie Louvet-Vallée, Marek Maleszewski, Yusuke Marikawa, Bernard Maro and Davor Solter

Int. J. Dev. Biol. (2006) 50: 581-588

Principles of branch formation and branch patterning in Hydrozoa

Stefan Berking

Int. J. Dev. Biol. (2006) 50: 123-134

Head-tail patterning of the vertebrate embryo: one, two or many unresolved problems?

Claudio D. Stern, Jeroen Charité, Jacqueline Deschamps, Denis Duboule, Anthony J. Durston, Marie Kmita, JeanFrançois Nicolas, Isabel Palmeirim, Jim C. Smith and Lewis Wolpert

Int. J. Dev. Biol. (2006) 50: 3-15

Antero-posterior patterning of the vertebrate digestive tract: $\mathbf{4 0}$ years after Nicole Le Douarin's PhD thesis Anne Grapin-Botton

Int. J. Dev. Biol. (2005) 49: 335-347

Single-cell transcriptional profiles and spatial patterning of the mammalian olfactory epithelium Ian Tietjen, Jason Rihel and Catherine G. Dulac

Int. J. Dev. Biol. (2005) 49: 201-207 